\title{
Herbal Medicines Intended for Correction of Digestive System Diseases
}

\author{
EV Ferubko ${ }^{1 *}$, TD Rendyuk ${ }^{2}$, TD Dargaeva', SM Nikolaev³
}

\section{EV Ferubko ${ }^{1, *}$, TD Rendyuk ${ }^{2}$, TD Dargaeva', SM Nikolaev ${ }^{3}$}

'All-Russian Research Institute of medicinal and Aromatic Plants, Moscow, RUSSIA.

${ }^{2}$ Sechenov First Moscow State Medical University, Moscow, RUSSIA.

Institute of General and Experimental Biology of the Siberian Branch of the RAS Ulan-Ude, RUSSIA.

\section{Correspondence \\ EV Ferubko}

Head of department of experimental pharmacology, All-Russian scientific research institute of Medicinal and Aromatic plants, RUSSIA.

E-mail: eferubko@yandex.ru

History

- Submission Date: 12-12-2021;

- Review completed: 04-01-2022;

- Accepted Date: 10-01-2022.

DOI : 10.5530/pj.2022.14.17

Article Available online http://www.phcogj.com/v14/i1

Copyright

(C) 2022 Phcogj.Com. This is an open access article distributed under the terms of the Creative Commons Attribution 4.0 International license.

\begin{abstract}
Purpose: Studying the assortment of herbal medicines (HMs) available in the Russian Federation and generalizing the use experience of them in gastroenterological practice. Methods: Information and analytical. Results: The analysis of the State Register of Medicines Permitted for Use in Medical Practice, as well as foreign and domestic publications from authoritative international databases, has been carried out. The limited range of drugs prescribed for diseases of the digestive system was revealed. The advantages of using complex drugs in comparison with monopreparations are shown. Conclusion: It is necessary to develop new multicomponent HMs of high therapeutic efficacy and low toxicity for prevention and treatment of digestive system diseases.
\end{abstract}

Key words: Herbal medicines, Digestive system diseases, Correction.

\section{INTRODUCTION}

Currently, the urgent task of medical science is to expand research to reveal sources for obtaining new effective and safe herbal medicines (HMs), including those used in gastroenterological practice. It is of especially importance given that the share of herbal drugs (HDs) used in practical health care is more than $40 \%$. One of the ways to increase the number of herbal preparations is a comprehensive study of the action of already known pharmacopoeial medicinal plants often used for a limited number of indications, as well as the composing of rational multicomponent herbal species (collections), which are the most popular, available to the population and contain biologically active substances with versatile pharmacological action for the correction of many interconnected body systems.

In recent years and in many countries, there has been a steady increase in gastroenterological diseases associated with unfavorable environmental conditions and poor nutrition. In Russia, every tenth inhabitant suffers from diseases of the same group. The most common diseases are chronic pancreatitis (8-35\%), gastric ulcer and duodenal ulcer ( $8-10 \%)$, diseases of the hepatobiliary system including hepatitis (8-22\%). These diseases are complicated by the development of dysbiosis, which is detected in more than $90 \%$ of patients with acute and chronic gastroenterological diseases and in almost all patients having acute intestinal infections. At the same time, the balance between different types of intestinal microorganisms is disturbed in a body, pathogenic and conditionally pathogenic flora is revealed, general metabolic disorders and neurohumoral disorders develop. In addition, there is an increase in the number of patients with a severe course of diseases of the digestive system, the development of complications, an increase in the percentage of malignant neoplasms of the stomach, pancreas, which leads to an increase in mortality and disability of the population. In this regard, the problem of restoring the functional activity of the digestive organs, the prevention of seasonal exacerbations is relevant and rather complicated..$^{1-7}$

The pathology of the digestive system is not only chronic, but also combined in nature. Diverse synthetic drugs having pronounced therapeutic effect is widely used in the therapy. However, these medicines are not devoid of side effects, they have contraindications and restrictions for use, and do not always prevent the development of a relapse of the disease after the cancellation. This all determines the need to develop comprehensive approaches to the treatment of digestive system disorders, including the use of HMs, which have a wide range of therapeutic and prophylactic effects, have low toxicity, mild action, and are able to quickly eliminate symptoms of exacerbation, prevent relapses and help restore disturbed functions of the gastrointestinal tract. The possibility of a rational combination of medicinal plants with each other and with synthetic drugs makes it possible to expand their therapeutic capabilities and reduce the frequency of side effects of drug therapy. The foregoing determined the purpose of the research that is to study the range of HMs available in the Russian Federation, and to generalize the experience of use them in gastroenterological practice.

\section{MATERIALS AND METHODS}

We used different sources of necessary data published in scientific literature including reputable electronic databases such as PubMed, Google Scholar, Scopus, Web of Science, e-Library, as well as normative documentation.

\section{RESULTS}

In order to determine the use ranges of herbal medicinal products (HMPs) available in the territory of the Russian Federation, an analysis of the State 
Table 1: Distribution of herbal medicinal products by groups.

\begin{tabular}{lc}
\hline Name of the group & Share of the group, \% \\
\hline $\begin{array}{l}\text { Herbal drug raw materials (HDRM). It includes certain types of raw materials; it may be dried, less often freshly harvested parts } \\
\text { of medicinal plants (optionally whole plants). }\end{array}$ & 31,4 \\
Herbal medicinal compositions. They are mixes of few kinds of grinded or, less commonly, whole HDRM, optionally may contain \\
salts and/or essential oils.
\end{tabular}

Register of Medicines Permitted for Use in Medical Practice was carried out. It showed that at present more than 500 names of HMs have been registered, which differ in component composition, methods of preparation and purification. Taking into account the share of each in the total number of HMPs, the following groups can be distinguished (Table 1).

The study of the domestic HMPs assortment by types of therapeutic action shows that they belong to more than 20 pharmacotherapeutic groups. ${ }^{8}$ Of these, 12 groups can be distinguished, which are used for treatment diseases of the digestive system, relatively evenly distributed in each group. The largest share among the drugs used in gastroenterological practice is occupied by choleretic (22.3\%), laxatives (19.5\%), anti spastic (17.4\%) HMPs. Astringents, appetite stimulants (bitterness) and hepatoprotectors account for $10 \%, 7.1 \%$ and $5.6 \%$, respectively. Less than $5 \%$ falls on the share of antiulcer, enveloping, enzymatic, anti hemorrhoidal and carminative HMPs. Also, herbal medicines of combined action were revealed, amounting to $13.1 \%$. A wide range of herbal medicines of these groups is represented by the following preparations made both in Russia and in others countries: ${ }^{8}$ choleretic HMs: Russian-made - roots and leaves of barberry (drug name is berberine bisulfate), everlasting flowers (dry extract, drug name is flamin), corn stigmas and styles (liquid extract), water shamrock leaves, tansy flowers (drug name is tanacehol), coriander fruits, dandelion roots, celandine herb, and following drus: holosas (based on dog rose hips), allochol (nettle and garlic extracts), bilignin (lignin obtained from lignified plant tissues), convaflavin (the sum of flavonoids from Keiske lily-of-the-valley herb); flacumin (from smoke tree leaves), sibektan (extracts of birch leaves, goatweed herb, silimar, tanacehol); foreign made - legalon, silymarin, carsil, silibor (from milk thistle fruits), artecholine (a complex preparation containing yarrow, mint, celandine, wormwood, dandelion, milk thistle, etc.); holagogum (a complex preparation containing extracts of celandine, turmeric, spinach, oils of peppermint and turmeric, phospholipids); herbal laxatives: Russian-made - buckthorn bark (drug name is ramnil), buckthorn fruits, senna leaves (dry senna extract, anthrasennin), rhubarb roots (rhubarb root tablets), castor oil, cafiol, complex licorice powder, laminaride (sum seaweed preparation); foreign made - based on senna leaves (senade, senadexin), complex preparations: agiolax (the sum of senna active ingredients, flea plantain, chamomile); kalifig (senna extract, figs, clove oil, peppermint oil); mucofalk (hydrophilic fibers from the outer shell of plantain ovate seeds); depuraflux (buckthorn bark, anise fruits, seeds of caraway, coriander, fennel; peppermint leaves, senna leaves, centaury and horsetail herbs); regulax (powder of senna leaves and fruits, fig paste, plum mousse and excipients); antispasmodic HMs: Russian-made - preparations based on Belladonna vulgaris (besalol, bellastezin, bacarbon, bellalgin, gastric tablets with belladonna extract, complex tinctures: tincture of valerian, wormwood, belladonna, mint and tincture of valerian, wormwood, belladonna); peppermint leaves (mint tablets); fruits of fennel, dill, coriander, cumin; chamomile flowers; datiscan (total preparation from false hemp leaves); foreign made - plantex (contains fennel fruit extract, fennel essential oil, excipients); containing bitterness and used to improve digestion, the activity of the digestive glands and to stimulate appetite: Russian-made - calamus rhizomes, centaury grass, dandelion roots, water shamrock leaves, herb and tincture of wormwood, bitter tincture (centaury herb and water trefoil leaves, calamus rhizomes, wormwood herb, coriander fruits); foreign made - the complex drug Livomin; astringent herbal products: Russian-made - rhizomes of serpentine, bergenia, cinquefoil, burnet, bird cherry, blueberry, alder seed; the drug tanalbin (a product of the interaction of tannins from leaves of smoke tree and sumach), tansal; herbal hepatoprotectors: Russian-made - pumpkinol (from pumpkin seeds), vigeratin, silimar, silibor, silymarin, silistrong (from milk thistle); foreign made - LIV-52 (the complex drug containing several herbal components); hepatofalk planta (milk thistle fruit extract, celandine and javaneseturmel extract); gastroprotectors, antiulcer and enveloping HMs: Russian-made marshmallow and licorice roots, calamus rhizomes, elecampane rhizomes and roots, marsh cudweed herb, Greek valerian rhizome and roots, flax seeds, flea plantain seeds; drugs: alantone (from elecampane rhizomes with roots), vikair, vicalin (from calamus rhizomes), caleflon (from calendula flowers, gastrophyte (a complex preparation containing calendula, buckthorn, chamomile, yarrow, and fennel oil), gastrofungin, befungin (the sum of phenolic compounds from birch fungus Polyporus betulinus), liquiriton, flacarbin (from licorice roots); foreign made - romazulan (from chamomile flowers);

HMs affecting the secretion of hydrochloric acid: Russian-made - drugs that increase secretion from the leaves of the plantain (plantain juice, plantain tincture, plantaglucid); foreign made - a drug that lowers the secretion, alcid B, containing an extract of licorice, chamomile, buckthorn bark, coriander fruits, fennel and auxiliary substances; antihemorrhoidal HMs: Russian-made - redshank herb, restharrows roots (tincture), suppositories anuzol, betiol; foreign made - ginkorprocto suppositories; herbal enzyme preparations: nigedaza (from ragged lady (Nigella damascena ) seeds);

HMs of combined action: elixirs Demidovsky, Vivaton, Muscovy balms, Panta-Forte, Pervoprestolny, Bittner's balm, Maurer's balm.

Summarizing the range of medicinal products by types of dosage forms, it was found that the predominant share - $31.4 \%$ - is occupied by individual types of medicinal products, extracts' share is $11.2 \%$, substances $5.7 \%$, briquettes $6.0 \%$, compositions $5.5 \%$. HMs presented in liquid dosage forms (tinctures, drops, oils, syrups, elixirs, balms, oral solutions) have a share of $19.5 \%$, solid dosage forms (tablets, granules, powders, capsules) $-18.7 \%$, an insignificant share falls on soft dosage forms (suppositories) $-2.0 \%$.

Analysis of the HMP assortment based on the raw materials contained in them showed that most often medicinal plants included in the prescriptions used in gastroenterological practice are chamomile, senna, buckthorn, mint, calamus, elecampane, fennel, coriander, everlasting, belladonna, wormwood, goatweed, milk thistle, etc.

Among the officinal multicomponent herbal compositions belonging to various nosological groups, more than 40 have been registered in the State Register of Medicines. ${ }^{8,9}$ However, it can be noted that only 11 
Table 2: Official herbal preparations recommended for diseases of the digestive system.

\begin{tabular}{|c|c|c|c|c|}
\hline No & Name & Composition & Pharmachologic effect & Indications for use \\
\hline 1 & Gastrointestinal No 1 & $\begin{array}{l}\text { Chamomile flowers, peppermint leaves, } \\
\text { dill fruits, calamus rhizomes, licorice } \\
\text { roots by } 20 \%\end{array}$ & $\begin{array}{l}\text { Anti inflammatory, choleretic, } \\
\text { antimicrobial, anti spastic, anti } \\
\text { flatulent; tissue regeneration stimulant }\end{array}$ & $\begin{array}{l}\text { Gastritis with high acidity, gastric ulcer } \\
\text { and duodenal ulcer, chronic colitis, biliary } \\
\text { dyskinesia, spasms of smooth muscles of the } \\
\text { gastrointestinal tract, flatulence }\end{array}$ \\
\hline 2 & Gastral No 3 & $\begin{array}{l}\text { Buckthorn bark, nettle leaf by } 30 \% \text {, } \\
\text { peppermint leaves - } 20 \% \text {, calamus } \\
\text { rhizomes, and valerian roots and } \\
\text { rhizomes by } 10 \%\end{array}$ & Laxative, anti spastic & $\begin{array}{l}\text { Spasms of smooth muscles of the } \\
\text { gastrointestinal tract, constipation (spastic) }\end{array}$ \\
\hline 3 & Choleretic No 1 & $\begin{array}{l}\text { Sandy everlasting flowers - } 4 \text { parts, water } \\
\text { shamrock leaves }-3 \text { parts, peppermint } \\
\text { leaves - } 2 \text { parts, coriander fruits }-2 \text { parts }\end{array}$ & Choleretic & $\begin{array}{l}\text { Cholecystitis, hepatitis, cholangitis, } \\
\text { hepatocholecystitis }\end{array}$ \\
\hline 4 & Choleretic No 2 & $\begin{array}{l}\text { Sandy everlasting flowers - } 4 \text { parts, } \\
\text { yarrow herb, peppermint leaves, } \\
\text { coriander fruits - by } 2 \text { parts }\end{array}$ & Choleretic & $\begin{array}{l}\text { Cholecystitis, hepatitis, cholangitis, } \\
\text { hepatocholecystitis }\end{array}$ \\
\hline 5 & Choleretic No 3 & $\begin{array}{l}\text { Chamomile flowers, peppermint leaves, } \\
\text { marigold flowers, yarrow herb - by } 23 \% \text {, } \\
\text { tansy flowers - } 8 \%\end{array}$ & $\begin{array}{l}\text { Choleretic, anti inflammatory, anti } \\
\text { spastic; increases appetite, normalizes } \\
\text { gastrointestinal motility }\end{array}$ & $\begin{array}{l}\text { Diseases of the liver and biliary tract (acute } \\
\text { and chronic cholecystitis and hepatitis, } \\
\text { cholangitis, biliary dyskinesia, post } \\
\text { cholecystectomy syndrome) }\end{array}$ \\
\hline 6 & Anti flatulent & $\begin{array}{l}\text { Peppermint leaves, fennel fruits by } 34 \% \text {, } \\
\text { valerian roots and rhizomes - } 32 \%\end{array}$ & Anti flatulent, anti spastic & Flatulence \\
\hline 7 & LaxativeNo 1 & $\begin{array}{l}\text { Buckthorn bark - } 3 \text { parts, nettle leaf }-2 \\
\text { parts, yarrow herb - } 1 \text { part }\end{array}$ & Laxative & Chronic constipations \\
\hline 8 & Laxative No 2 & $\begin{array}{l}\text { Senna leaves - } 3 \text { parts, buckthorn bark, } \\
\text { buckthorn fruits - by } 2 \text { parts, anise fruits, } \\
\text { licorice roots - by } 1 \text { part }\end{array}$ & Laxative & Chronic constipations \\
\hline 9 & Anti hemorrhoidal & $\begin{array}{l}\text { Senna leaves, yarrow herb, buckthorn bark, } \\
\text { coriander fruits, licorice roots - by } 20 \%\end{array}$ & $\begin{array}{l}\text { Laxative, anti spastic, anti } \\
\text { inflammatory, hemostatic }\end{array}$ & Hemorrhoids, constipations \\
\hline 10 & $\begin{array}{l}\text { Appetite stimulating } \\
\text { composition }\end{array}$ & $\begin{array}{l}\text { Wormwood herb }-8 \text { parts, yarrow herb } \\
-2 \text { parts }\end{array}$ & $\begin{array}{l}\text { Stirs up appetite (bitterness), improves } \\
\text { digestion }\end{array}$ & To stimulate appetite \\
\hline 11 & Hepaphyte & $\begin{array}{l}\text { Marigold flowers - } 20 \% \text {, corn stigmas } \\
\text { and styles - } 20 \% \text {, knotweed herb, } \\
\text { goatweed herb, plantain leaves, rose hips } \\
\text { by } 13,33 \% \text {, dandelion roots }-6,67 \%\end{array}$ & $\begin{array}{l}\text { Choleretic, hepatoprotective and anti } \\
\text { inflammatory }\end{array}$ & $\begin{array}{l}\text { Cholecystitis, cholangitis, hepatitis, biliary } \\
\text { dyskinesia (treatment and prevention) }\end{array}$ \\
\hline
\end{tabular}

items are used in the treatment of the digestive system diseases (Table 2). Given the prevalence of pathology of the digestive system organs, this is definitely not enough.

In the State Register of Medicines, along with monopreparations, multicomponent LSRPs are registered, including in the form of fees. As you know, the action of multicomponent drugs compares favorably with the mutual enhancement of the pharmacological properties of each constituent component, the compliance with the polyvalence of the pathogenesis of the disease, the effect on the patient's body as a whole. ${ }^{10-13}$

Academician N.V. Vershinin together with M.N. Varlakov has been evaluated comprehensively the effectiveness of multicomponent HDs used in Tibetan medicine in experimental and clinical conditions. ${ }^{14}$ Subsequently, Professor A.N. Kudrin (1956) proposed a theory for the preparation of combined drugs based on the complex drug research. Its essence lies in the inclusion in the complex of three main groups of medicinal substances aimed at eliminating (diminution) the cause of the disease, reducing pathogenetic changes in the patient's body and strengthening (mobilizing) the compensatory-adaptive mechanisms in the patient organism. ${ }^{14,15}$ The pronounced effectiveness of such drugs, which are a systemic composition, is ensured first of all by restoring the balance between regulatory systems, as well as direct correction of the damaged organ function. ${ }^{14}$

Reliability in the complex drug action is increased due to the ingredients included in the complex have unidirectional types of pharmacological activity but different action mechanisms, therefore the effects are duplicated.
Complex medicines have a number of advantages, such as ease of use; potentiation of effects; limiting the risk of adverse reactions; reduction in the cost of the drug; systemic action of the complex as a pharmacotherapeutic system. ${ }^{13-20}$ HMs including multicomponent ones provide balancing and normalization of regulatory mechanisms, activating and mobilizing the adaptive, compensatory-adaptive capabilities of the body..$^{10,14,19,21}$

\section{CONCLUSION}

Taking into account the above data and on the basis of information and analytical analysis of foreign and domestic publications, it can be concluded that the range of HMPs prescribed for diseases of the digestive system is limited. Based on this, the research on the creation and development of new multicomponent HMs of high therapeutic efficacy and low toxicity for the prevention and treatment of the digestive system diseases are an urgent challenge for modern pharmacology and pharmacy.

\section{FUNDING}

The research was carried out within the framework of the research plan on the topic "Directed screening, evaluation of pharmacological activity and safety of biologically active substances and pharmaceutical compositions based on them" (FGUU-2022-0010).

\section{ACKNOWLEDGEMENT}

None. 


\section{CONFLICTS OF INTEREST}

The authors declare no conflicts of interest.

\section{REFERENCES}

1. Morbidity of the population of the Russian Federation. 2021.

2. Kurkin VA, Petrukhina IK. Actual aspects of development importsubstituting herbal medicines. Fundamental research. 2014;2:366-371.

3. Sherlock S, Dooley J. Diseases of the Liver and Biliary System. 13th edition. London: Blackwell. 2018;813.

4. Hirschfield GM, Heathcote EJ, Gershwin ME. Pathogenesis of cholestatic liver disease and therapeutic approaches. Gastroenterology. 2010;139:1481-96.

5. Zhang $A$, Sun $H$, Wang $X$. Recent advances in natural products from plants for treatment of liver diseases. European Journal of Medicinal Chemistry. 2013;63:570-7.

6. Prete AD, Scalera A, ladevaia MD, Miranda A, Zulli C, Gaeta L, et al. Herbal products: benefits, limits and applications in chronic liver disease. Evidence-Based Complementary and Alternative Medicine. 2012;837939:19.

7. Ghosh N, Ghosh R, Mandal V, Mandal S. Recent advances in herbal medicine for treatment of liver diseases. Pharmaceutical Biology. 2011;49:970-88.

8. State Register of Medicines. The Russian Federation Ministry of Health. 2021

9. State Pharmacopoeia of Russian Federation, XIV ed., Vol. IV Federal. electronic medical library. 2021.

10. Nikolaev SM, Mondodoev AG, Shantanova LN. Prospects for the use of multicomponent drugs in the pharmacotherapy of diseases. Medicus. 2015;6(6):139-41.

11. Osetrova OI. On the optimal amount of ingredients in recipes (on the example of the use of common bistort). First Republican Conference on Medical Botany Abstracts. Kiev: "Naukova Dumka". 1984;182-3.
12. Fauron R, Moatti R, Donadieu G. Guide pratique de phytotherapie. Encyclopediemedicale de prescription phytotherapique. Paris: Maloine. 1984;840.

13. Dargaeva TD, Lyakina MN, Sokolskaya TA. Principles of the preparation of multicomponent drugs in Tibetan medicine. Moscow: Scientific and Practical Center for Traditional Medicine and Homeopathy of the Ministry of Health of the Russian Federation. 2000;244-6.

14. NikolaevSM.Phytopharmacotherapyandphytopharmacoprophylaxis of diseases. Ulan-Ude: Buryatia State University Publishing House. $2012 ; 286$.

15. Lubsandorzhieva P. Development and standardization of herbal medicines for the treatment and prevention of digestive system diseases. Ulan-Ude: Publishing house of Buryatia Scientific Center of Siberian Branch of the Russian Academy of Sciences. 2016;280.

16. Weiss RF, Fintelmann F. Phytotherapy. Manual: translation from German. Moscow: Medicine. 2004; 552.

17. Bao Y-F, LiJ.-Y, ZhengL-F. Antioxidant activities of cold-nature Tibetan herbs are significantly greater than hot-nature ones and are associated with their levels of total phenolic components. Chinese Journal of Natural Medices. 2015;13(8):609-17.

18. Belaiche P. Traite de Phytotherapie et d'Aromatherapie. Vol. 2. Les Moladiesinfoctitnses. Paris. 1979;442.

19. Goldman P. Herbal medicines today and the roots of modern pharmacology. Ann. Intern. Med. 2001;135(8):594-600.

20. Guo D, Lu A, Liu L. Modernization of traditional Chinese medicine. Journal of Ethnopharmacology. 2012;141:547-8.

21. Kiseleva TL. Kinetic synergism in phytotherapy: traditional drugs from the point of view of modern scientific concepts. Traditiona medicine. 2011;2:50-7.

\section{GRAPHICAL ABSTRACT}

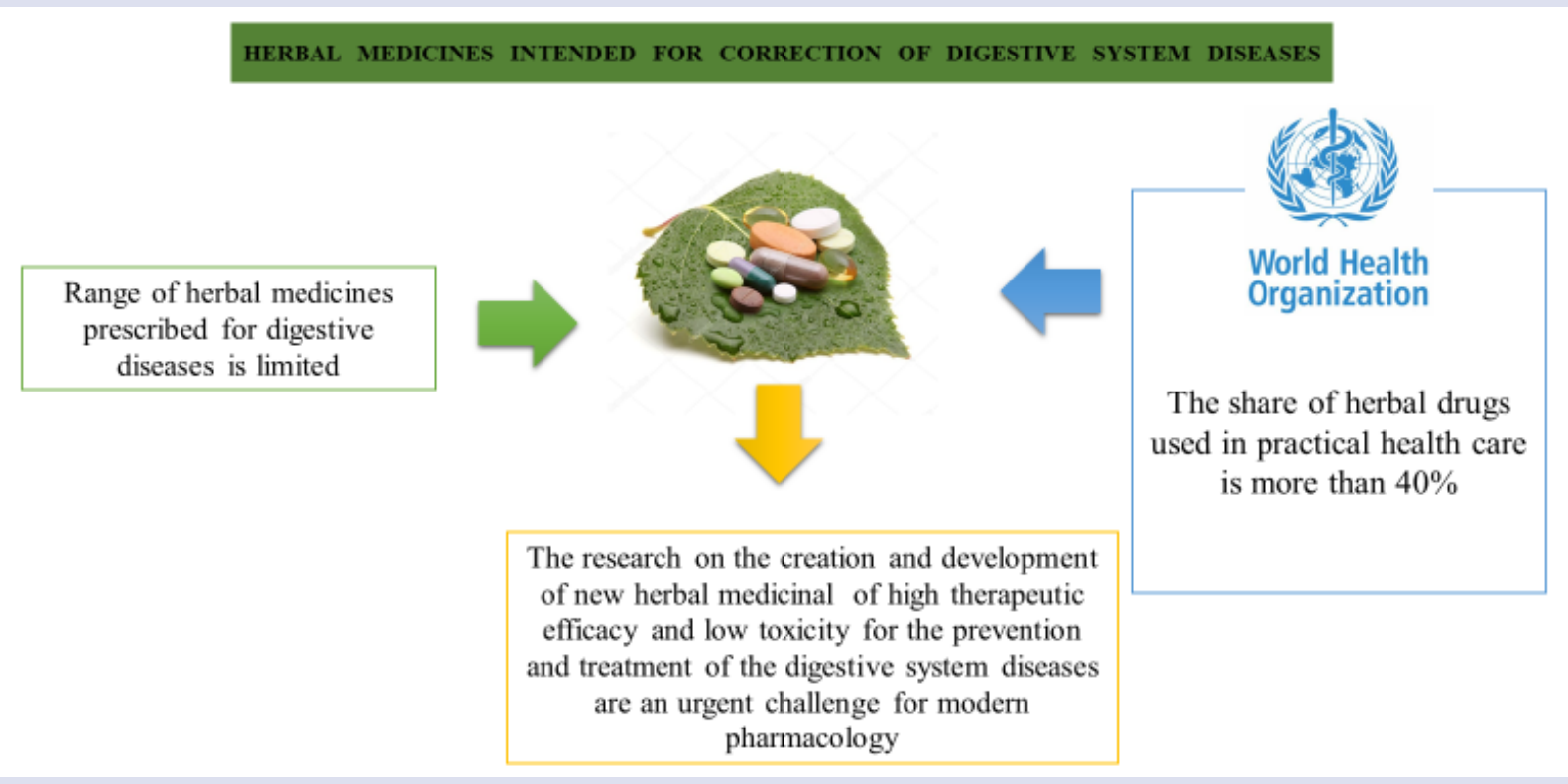




\section{ABOUT AUTHORS}

Ferubko Ekaterina Vladimirovna: Doctor of Medical Sciences, Head of Department of Experimental Pharmacology, All-Russian Research Institute of Medicinal and Aromatic Plants (Moscow, Russia). Research interests: the study of targeted pharmacological activity and toxicology of promising herbal medicines.

Randyuk Tamara Danilovna: Candidate of Pharmaceutical Sciences, Associate Professor, Department of Pharmaceutical natural Sciences, Institute of Pharmacy, Sechenov University (Moscow, Russia). Research interests: search for promising sources of biologically active substances and the creation on their basis of highly effective herbal medicines

Dargaeva Tamara Darizhapovna: Doctor of Pharmaceutical Sciences, Professor, Chief Researcher at the Department of Chemistry of Natural Compounds, All-Russian Research Institute of Medicinal and Aromatic Plants (Moscow, Russia). Research interests: search for promising sources of biologically active substances and the creation on their basis of highly effective herbal medicines.

Nikolaev Sergey Matveevich: Doctor of Medical Sciences, Chief Researcher at the Laboratory for the Safety of Biologically Active Substances of the Institute of General and Experimental Biology of the Siberian Branch of the RAS (Russia, Ulan-Ude). Research interests: the study of targeted pharmacological activity and toxicology of promising herbal medicines.

Cite this article: Ferubko EV, Rendyuk TD, Dargaeva TD, Nikolaev SM. Herbal Medicines Intended for Correction of Digestive System Diseases. Pharmacogn J. 2022;14(1): 128-132. 